\title{
FRACTIONAL CRYSTALLIZATION LABORATORY TESTING FOR INCLUSION AND CO-PRECIPITATION WITH ACTUAL TANK WASTE
}

R. W. Warrant

CH2M HILL Hanford Group, Inc.

Richland, WA 99352

U.S. Department of Energy Contract DE-AC27-99RL14047

$\begin{array}{ll}\text { EDT/ECN: DRF } & \text { UC: } \\ \text { Cost Center: } 75110 & \text { Charge Code: } \\ \text { B\&R Code: } & \text { Total Pages: } 26\end{array}$

Key Words: fractional, crystallization, tank, waste, saltcake, S-farm, feed, Cesium-137, sodium, separations, decontamination factor, pretreatment, inclusion, co-precipitation

Abstract: Laboratory-scale tests of the fractional crystallization process for contaminant inclusions and co-precipitation were conducted with actual tank waste samples in a hot cell at the 222-S Laboratory. The primary factors that influence the separation efficiency are solid/ liquid separation efficiency, contaminant inclusions, and co-precipitation. This is a report of test results for the latter two factors in NaNO3, $\mathrm{Na} 2 \mathrm{CO} 3, \mathrm{Na} 6 \mathrm{CO} 3(\mathrm{SO} 4) 2$, and $\mathrm{Na} 2 \mathrm{C} 20$ solid phases.

TRADEMARK DISCLAIMER. Reference herein to any specific commercial product, process, or servico by trade name, trademark, manufacturer, or otherwise, does not necessarily constitute or imply its endorsement, recommendation, or favoring by the United States Government or any agency thereof or its contractors or subcontractors.

Printed in the United States of America. To obtain copies of this document, contact: Document Control Services, P.O. Box 950, Mailstop H6-08, Richland WA 99352, Phone (509) 372-2420; Fax (509) 376-4989.
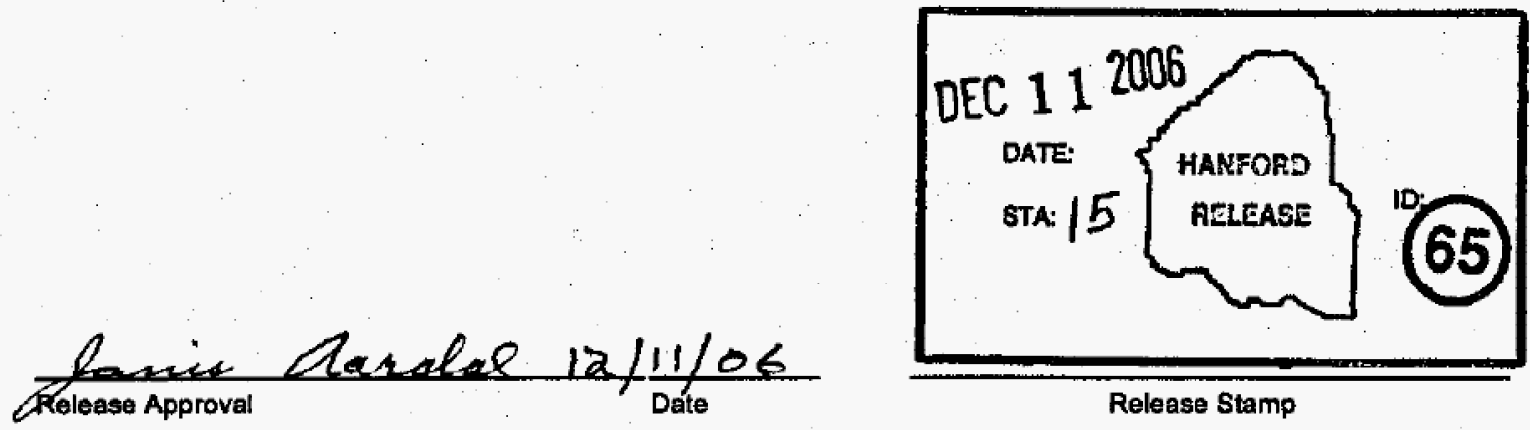

Release Stamp 
R. W. Warrant

Center for Laboratory Sciences

Columbia Basin College

Date Published

December 2006

\section{CH2IMHILL \\ Hanford Group, Inc.}

Prepared for the U.S. Department of Energy

Office of River Protection

Contract No. DE-AC27-99RL14047 
TABLE OF CONTENTS

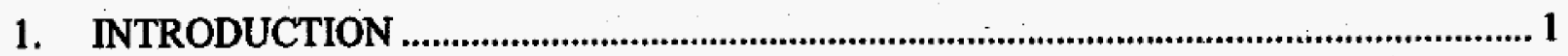

1.1 TEST SUMMARY AND RESULTS ……..................................................... 1

1.2 PRIOR TESTS WITH ACTUAL TANK WASTE ……....................................... 2

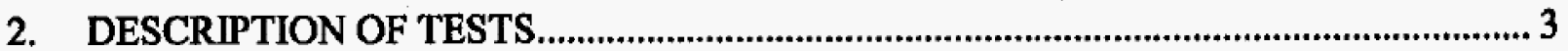

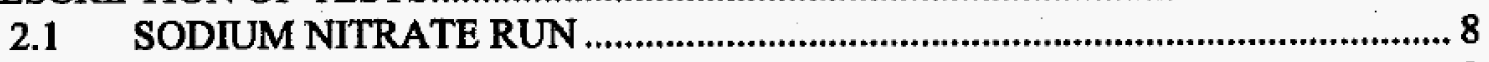

2.2 SODIUM CARBONATE RUN

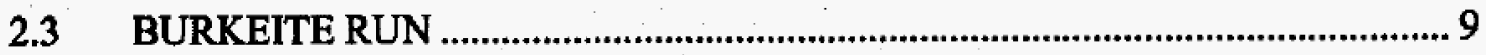

2.4 SODIUM OXALATE RUN ........................................................................ 10

3. TOTAL ACTIVITY AND RADIONUCLIDE ANALYSES .............................................11

4. RESULTS

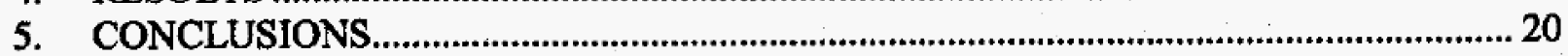

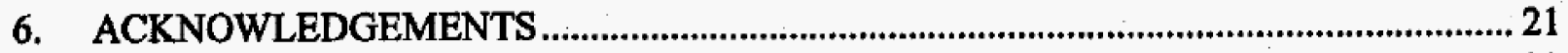

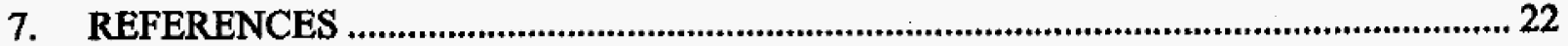

\section{LIST OF FIGURES}

Figure 2-1. Schematic Drawing of Boildown Apparatus.............................................................. 3

Figure 2-2. Diagram of the $\mathrm{NaNO}_{3} \mathrm{Run}$. ............................................................................... 4

Figure 2-3. Diagram of the $\mathrm{Na}_{2} \mathrm{CO}_{3} \mathrm{Run}$................................................................................... 5

Figure 2-4. Diagram of the $\mathrm{Na}_{6} \mathrm{CO}_{3}\left(\mathrm{SO}_{4}\right)_{2}$ Run........................................................................6

Figure 2-5. Diagram of the $\mathrm{Na}_{2} \mathrm{C}_{2} \mathrm{O}_{4}$ Run.......................................................................

Figure 3-1. Total Activity vs. Number of Washes for Evaporation Samples..............................13

Figure 3-2. Total Activity vs. Number of Washes for Wash Samples. ......................................... 14

\section{LIST OF TABLES}

Table 2-1. Composition of SST Early and SST Late Feed Solutions.............................................. 8

Table 3-1. Analytical Methods for Washed Solids and Filtrate Samples....................................... 11

Table 3-2. Results of Radionuclide Analyses for Filtrates and Solids. ......................................... 12

Table 3-3. Results of Total Activity Analyses for Wash Solutions............................................ 13

Table 4-1. Estimated Decontamination Factors and Percent of Initial Radionuclides Trapped

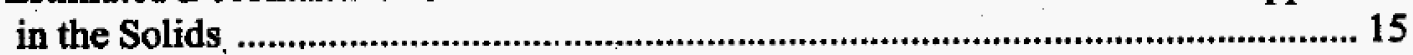

Table 4-2. Ratios of Radionuclides to Cesium-137...................................................................... 18

Table 4-3. Ratios of Radionuclides to Cesium-137 Normalized to Feed Solution...................... 19

Table 5-1. All Tests Exceed Cesium-137 Activity in Product Performance Criteria.................. 20 
RPP-RPT-31998, Rev. 0

\section{INTRODUCTION}

Fractional crystallization is being considered as a pretreatment method to support supplemental treatment of retrieved single-shell tank (SST) saltcake waste at the Hanford Site. The goal of the fractional crystallization process is to optimize the separation of the radioactivity (radionuclides) from the saltcake waste and send it to the Waste Treatment and Immobilization Plant and send the bulk of the saltcake to the supplemental treatment plant (bulk vitrification). The primary factors that influence the separation efficiency are (1) solid/liquid separation efficiency, (2) contaminant inclusions, and (3) co-precipitation. This is a report of testing for factors (2) and (3) with actual tank waste samples. For the purposes of this report, contaminant inclusions are defined as the inclusion of supernatant, containing contaminating radionuclides, in a pocket within the precipitating saltcake crystals. Co-precipitation is defined as the simultaneous precipitation of a saltcake crystal with a contuminating radionuclide. These two factors were tested for various potential fractional crystallization product salts by spiking the composite tank waste samples (SST Early or SST Late, exteraal letter CH2M-0600248, "Preparation of Composite Tank Waste Samples for EM-21 Froject") with the desired target salt and then evaporating to precipitate that salt. SST Early represents the typical composition of dissolved saltcake early in the retrieval process, and SST Late represents the typical composition during the later stages of retrieval. See Table 2-1 for: a summary of the compositions of both feed solutions.

Descriptions and historical background, theory, and application of the fractional crystallization process have been described in prior reports (RPP-RPT-26474, Fractional Crystallization of Waste from Tank 241-S-112; RPP-RPT-27239, Hanford Medium/Low Curie Waste Pretreatment Project - Phase I Laboratory Report; and RFP-RPT-31352, Fractional Crystallization Flowsheet Tests with Actual Tank Waste). Biiefly, the liquid waste formed during retrieval of saltcake waste from single-shell tanks represents the feed for the fractional crystallization process. Within the fractional crystallization plant, the waste is evaporated to form sodium salt crystals. The bulk of the radionuclides-especially ${ }^{137} \mathrm{Cs}$, ${ }^{99} \mathrm{Tc}$, and ${ }^{129} \mathrm{I}$-remain in the liquid phase. The slurry is filtered or centrifuged and the solids are washed to remove interstitial liquid. The high-activity filtrate or centrate is routed to a double-shell tank for storage and the spent wash solution is recycled to the evaporator. The washed solids are dissolved to create feed for a supplemental treatment and disposal facility.

\subsection{TEST SUMMARY AND RESULTS}

Four sodium salts were chosen for inclusion and co-precipitation testing:

a. Sodium nitrate $\left(\mathrm{NaNO}_{3}\right)$ in SST Early composite.

b. Sodium carbonate monohydrate $\left(\mathrm{Na}_{2} \mathrm{CO}_{3} \cdot \mathrm{H}_{2} \mathrm{O}\right)$ in SST Early composite.

c. Burkeite $\left[\mathrm{Na}_{6} \mathrm{CO}_{3}\left(\mathrm{SO}_{4}\right)_{2}\right]$ in SST Early composite.

d. Sodium oxalate $\left(\mathrm{Na}_{2} \mathrm{C}_{2} \mathrm{O}_{4}\right)$ in SST Late composite. 


\section{RPP-RPT-31998, Rev. 0}

Salt items $a, b$, and $c$ were chosen since they are the three major product salts identified in Phase I testing with SST Early simulants. Salt item $d$ was chosen as being a major phase on the evaporation of SST Late composite (see Table 2-1).

Test results showed that the radionuclides ${ }^{137} \mathrm{Cs},{ }^{99} \mathrm{Tc}$, and ${ }^{129} \mathrm{I}$ remain in the liquid phase with very little inclusion and that much of the ${ }^{90} \mathrm{Sr}$ co-precipitated with the solid phase and could not be washed out.

\subsection{PRIOR TESTS WITH ACTUAL TANK WASTE}

Prior studies (WHC-EP-0915, Clean Salt Process Final Report) reported that contaminant inclusion of ${ }^{137} \mathrm{Cs}$ in $\mathrm{NaNO}_{3}$ was $0.14 \%$ of the total present in the feed and was carried out in acid conditions. The study reported here showed that $\sim 0.4 \%$ of the total ${ }^{137} \mathrm{Cs}$ was trapped in the crystallized $\mathrm{NaNO}_{3}$ and was carried out in basic conditions.

Past studies (WHC-EP-0915) also demonstrated that $\mathrm{NaNO}_{3}$ crystals can be cleanly decontaminated from all radionuclides, i.e., co-precipitation does not occur with $\mathrm{NaNO}_{3}$. However, that study did not look specifically at the ${ }^{90} \mathrm{Sr}$ which appeared to co-precipitate to some extent with $\mathrm{NaNO}_{3}$ crystals in the study reported here both in the initial precipitation with the evaporation apparatus and with recrystallization. The prior study looked at the total activity as the indicator for a clean salt and preformed multiple recrystallizations. Another difference in the studies is that the prior study was done under acidic conditions and this study was done under basic conditions, which may or may not make a difference in the ability to co-precipitate ${ }^{90} \mathrm{Sr}$ in $\mathrm{NaNO}_{3}$ (this study does not address that question). 


\section{RPP-RPT-31998, Rev. 0}

\section{DESCRIPTION OF TESTS}

The laboratory apparatus used in the 222-S hot cells is schematically shown in Figure 2-1. The diagrams of the experiments for each of the four solid phases are shown in Figures 2-2 through 2-5. The feed compositions are shown in Table 2-1. The parameters for the evaporation experiments, amount of spiking salt, condensate-to-feed ratio, and temperatures, were based on computer modeling using the OLI Envirommental Simulation Program (ESP). ${ }^{1}$

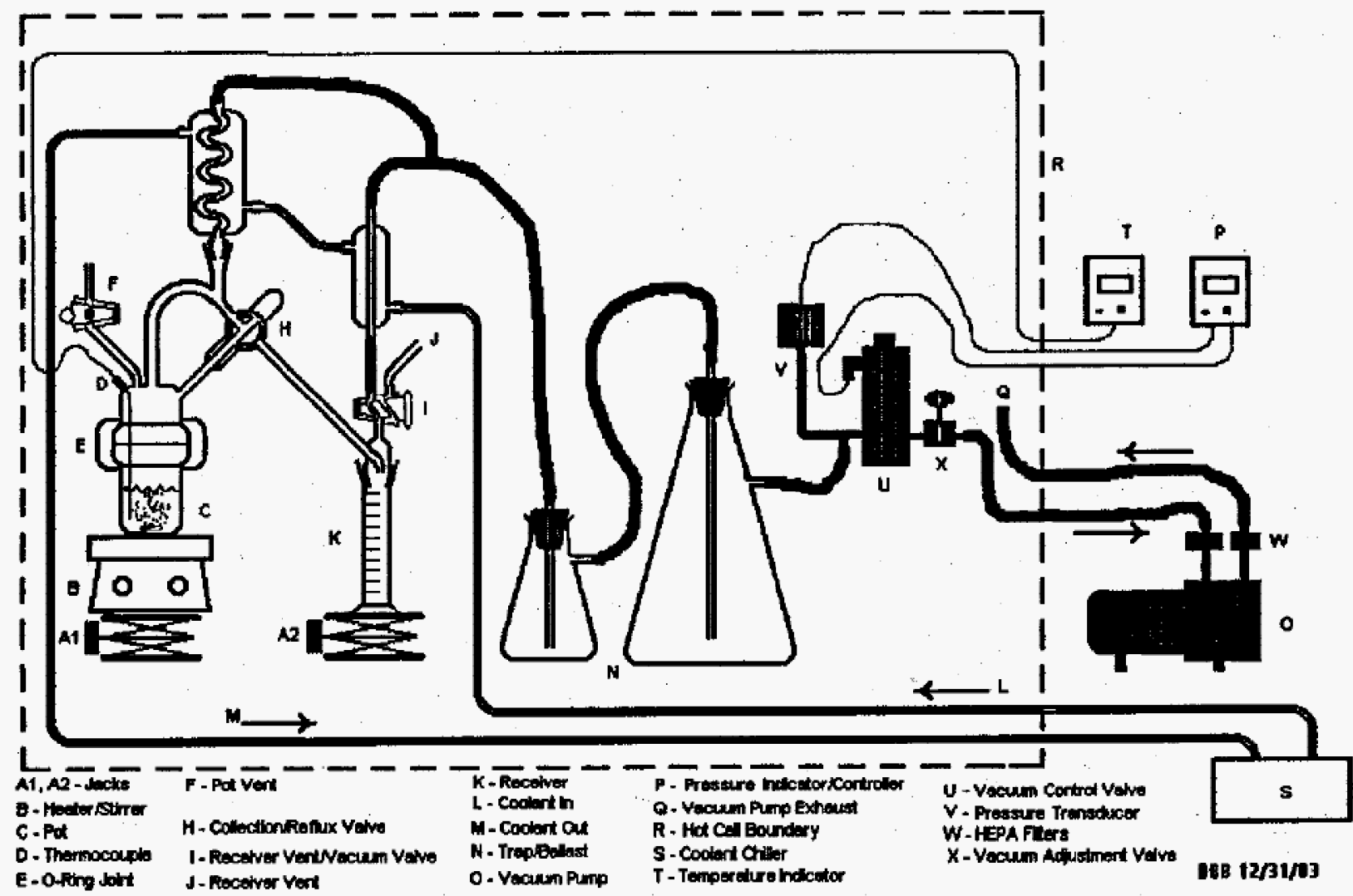

Figure 2-1. Schematic Drawing of Boildown Apparatus.

\footnotetext{
${ }^{1}$ Software product of OLI Systems, Inc., Morris Plains, New Jersey.
} 
RPP-RPT-31988, Rev. 0

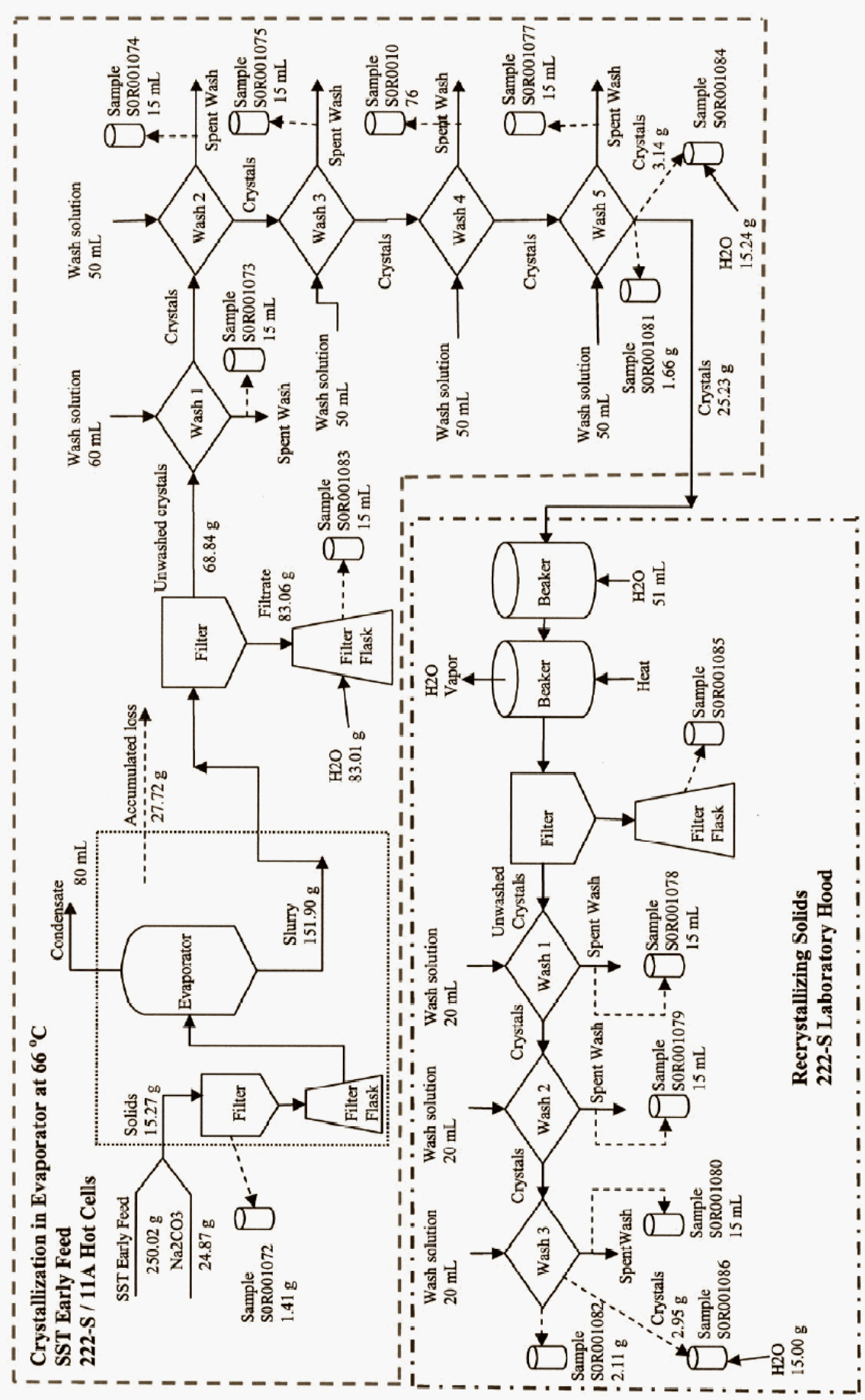


RPP-RPT-31988, Rev. 0

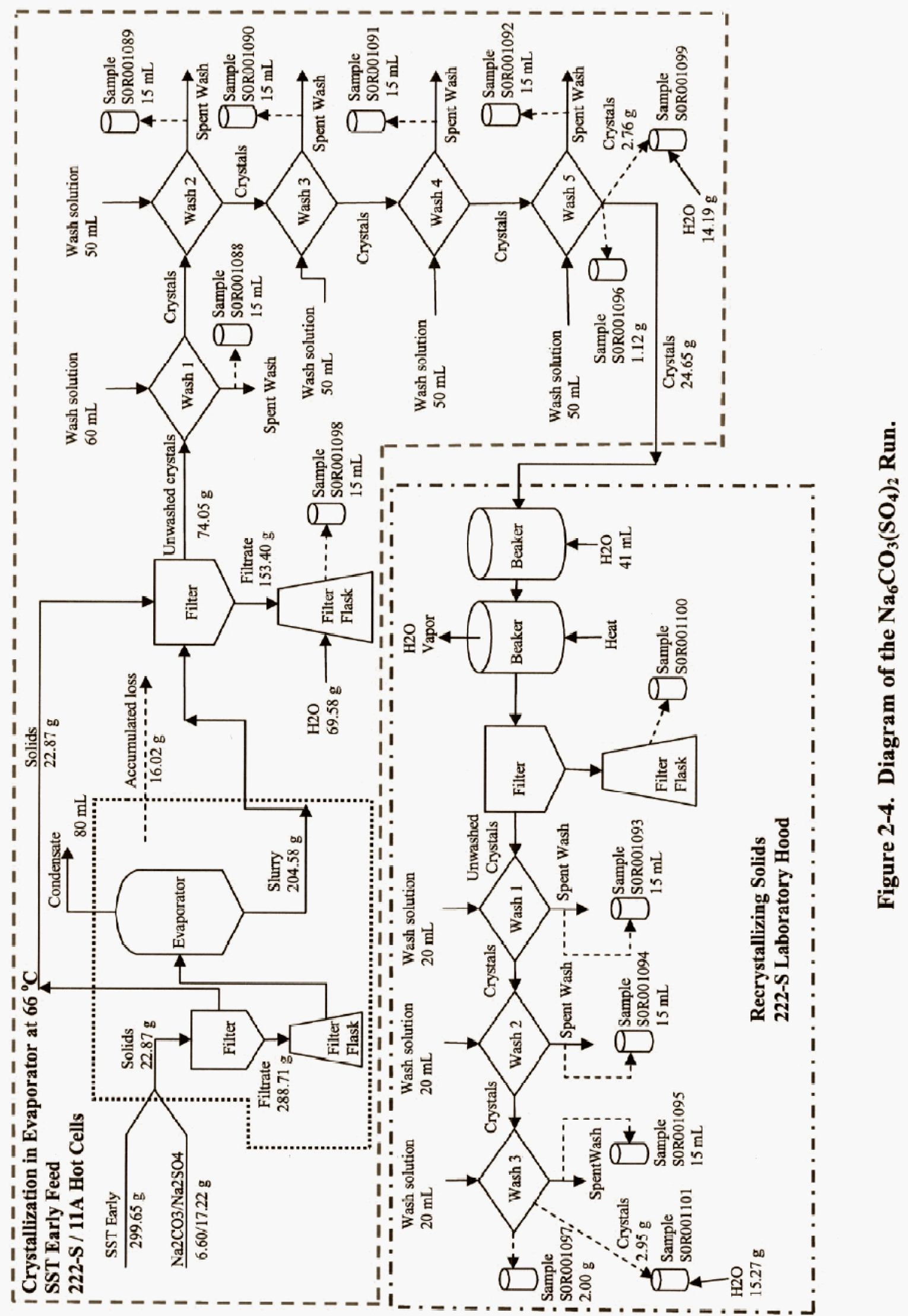

\footnotetext{
RPP-RP-31988, Rev. 0
} 
RPP-RPT-31988, Rev. 0

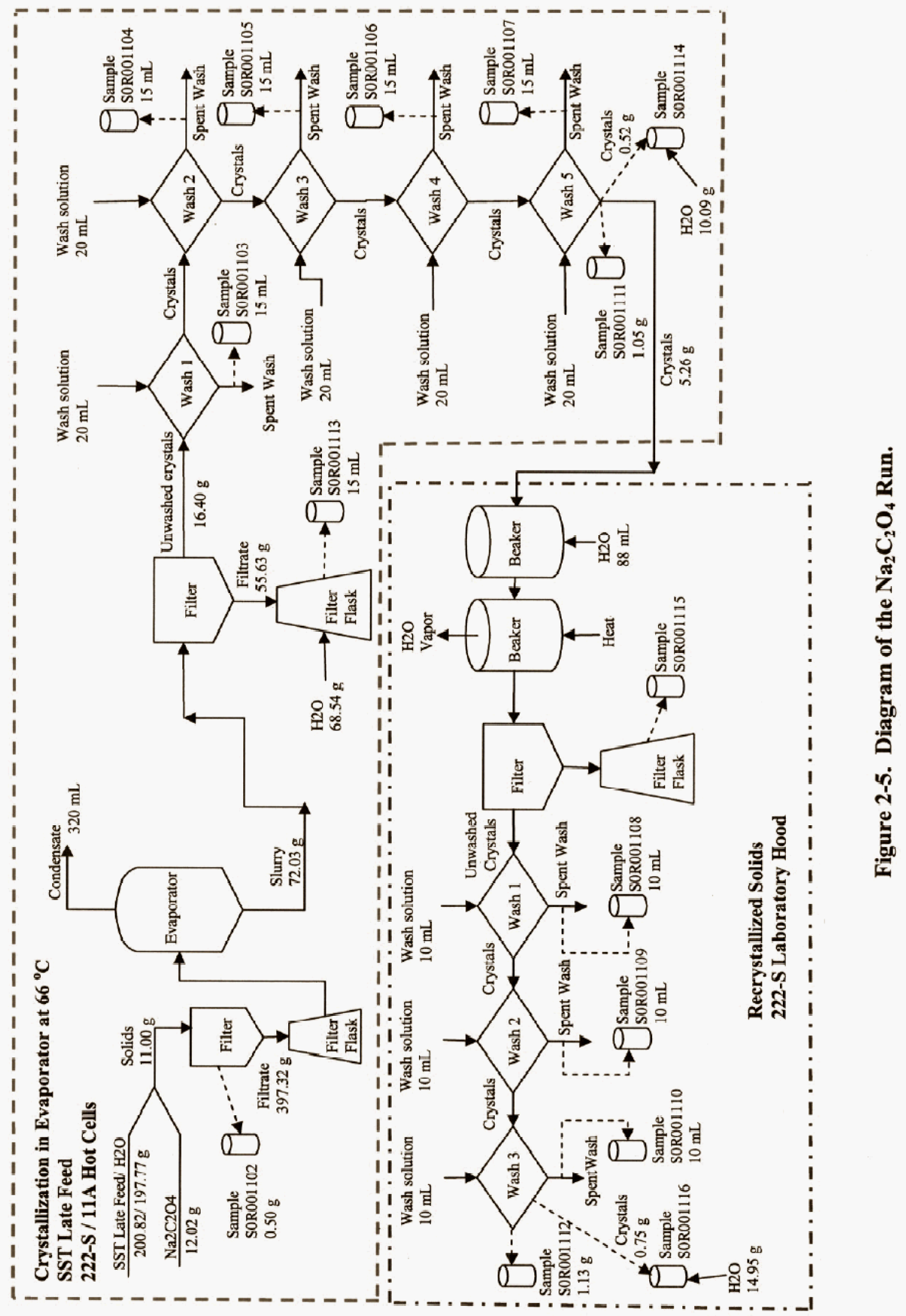


RPP-RPT-31988, Rev. 0

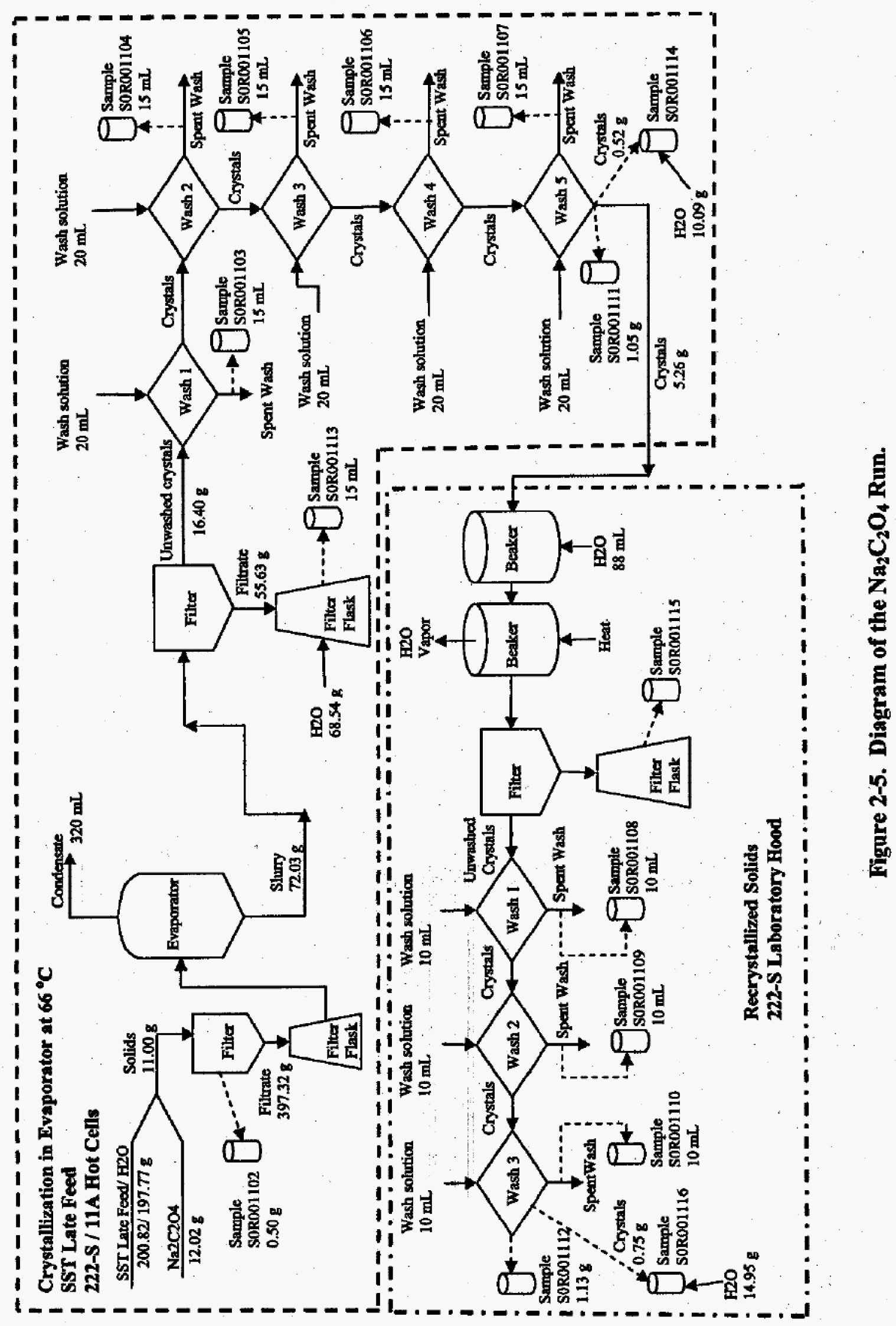


RPP-RPT-31998, Rev. 0

Table 2-1. Composition of SST Early and SST Late Feed Solutions.

(Analyte concentrations in molarity, except as noted)

\begin{tabular}{|c|c|c|c|}
\hline Analyte & SST Early & SST Late & EariyfLate \\
\hline $\mathrm{Wt}_{\mathrm{t}} \% \mathrm{H}_{2} \mathrm{O}$ & 57.8 & 89.4 & - \\
\hline Density, $\mathrm{g} / \mathrm{mL}$ & 1.32 & 1.06 & - \\
\hline $\mathrm{Al}$ & 0.289 & 0.039 & 7.4 \\
\hline $\mathrm{Cr}$ & 0.019 & 0.003 & 6.3 \\
\hline $\mathbf{K}$ & 0.018 & 0.003 & 6.0 \\
\hline $\mathrm{Na}$ & 6.309 & 1.201 & 5.3 \\
\hline $\mathbf{P}$ & 0.046 & 0.025 & 1.8 \\
\hline$S$ & 0.138 & 0.023 & 6.0 \\
\hline Si & 0.006 & 0.002 & 3.0 \\
\hline $\mathbf{F}$ & 0.010 & 0.052 & 0.2 \\
\hline $\mathrm{Cl}$ & 0,073 & 0.013 & 5.6 \\
\hline $\mathrm{NO}_{2}$ & 0.515 & 0.071 & 7.3 \\
\hline $\mathrm{NO}_{3}$ & 3.276 & 0.530 & 6.2 \\
\hline $\mathrm{PO}_{4}$ & 0.046 & 0.024 & 1.9 \\
\hline $\mathrm{SO}_{4}$ & 0.128 & 0.021 & 6.1 \\
\hline Oxalate & 0.006 & 0.054 & 0.1 \\
\hline $\mathrm{CO}_{3}$ & 0.614 & 0.099 & 6.2 \\
\hline TOC & 0.083 & 0.110 & 0.8 \\
\hline $\mathrm{OH}$ & 0.618 & 0.100 & 6.2 \\
\hline${ }^{137} \mathrm{Cs}, \mu \mathrm{Ci} / \mathrm{mL}$ & 59.9 & 9.40 & 6.4 \\
\hline${ }^{90} \mathrm{Sr}, \mu \mathrm{Ci} / \mathrm{mL}$ & 0.060 & 0.008 & 7.5 \\
\hline${ }^{129} \mathrm{I}_{2} \mu \mathrm{Ci} / \mathrm{mL}$ & $5.5 \mathrm{E}-5$ & $6.9 \mathrm{E}-6$ & 6.1 \\
\hline${ }^{99} \mathrm{Tc}_{2} \mu \mathrm{g} / \mathrm{mL}$ & 3.68 & 0.601 & 8.0 \\
\hline Mass balance & 92.7 . & 97.4 & - \\
\hline Charge balance $(+/-)$ & 0.98 & 0.97 & - \\
\hline
\end{tabular}

Note: Table taken from RPP-RPT-31352, 2006, Fractional Crystallization Flowsheet Tests with Actual Tank Waste.

\subsection{SODIUM NITRATE RUN}

The sodium nitrate run began with a charge of $129.82 \mathrm{~g}(98.3 \mathrm{~mL})$ of SST Early feed solution to the boiling pot and heated to $40^{\circ} \mathrm{C}$. While stirring, $32.26 \mathrm{~g}$ of $\mathrm{NaNO}_{3}$ were slowly added until completely dissolved. The boiling pot was attached to the boildown apparatus in the reflux position and the pressure and heat was adjusted to maintain constant boiling at $40^{\circ} \mathrm{C}$. After steady boiling was achieved, the valve was switched to collect condensate position and monitored until $\sim 39 \mathrm{~mL}$ were collected. The vacuum was released and the slurry was filtered with a jacketed filter apparatus at $40^{\circ} \mathrm{C}$. The filtrate was diluted with water to prevent precipitation and sampled. The filtered solids were washed five times with a saturated $\mathrm{NaNO}_{3}$ solution. The washed crystals and each of the spent wash liquid were sampled for analysis and the washed crystals were loaded out of the 222-S 11A hot cells to a 222-S Laboratory ventilation 
hood. X-ray diffraction (XRD) analysis on the washed crystals revealed them to be $\mathrm{NaNO}_{3}$ with no other phases detected.

The washed crystals were then redissolved in water and stirred and heated to near boiling in an open beaker until a freely flowing wet slurry was formed. The slurry was then filtered and the filtrate was sampled. The filtered solids were washed three times with saturated $\mathrm{NaNO}_{3}$ solution. The washed crystals and each of the spent wash liquids were sampled for analysis. The XRD analysis on the washed crystals revealed them to be $\mathrm{NaNO}_{3}$ with no other phases detected.

\subsection{SODIUM CARBONATE RUN}

The sodium carbonate run began with a charge of $250.02 \mathrm{~g}(189 \mathrm{~mL})$ of SST Early feed solution to the boiling pot and heated to $66^{\circ} \mathrm{C}$. While stirring, $24.87 \mathrm{~g}$ of anhydrous $\mathrm{Na}_{2} \mathrm{CO}_{3}$ were slowly added and continuously stirred for $\sim 1 \mathrm{hr}$. The stirred boiling pot continued to be cloudy and was filtered with a jacketed filter apparatus at $66^{\circ} \mathrm{C}$. The filtered solids were sampled for XRD analysis and the filtrate was returned to the boiling pot. The XRD analysis on the crystals revealed them to be primarily $\mathrm{Na}_{2} \mathrm{CO}_{3} \cdot \mathrm{H}_{2} \mathrm{O}$ with $\sim 10 \% \mathrm{NaNO}_{3}$ detected (the nitrate phase was most likely the result of the filtered crystals not being washed). The boiling pot was attached to the boildown apparatus in the reflux position and the pressure and heat was adjusted to maintain constant boiling at $66^{\circ} \mathrm{C}$. After steady boiling was achieved, the valve was switched to collect condensate position and monitored until $\sim 80 \mathrm{~mL}$ were collected. The vacuum was released and the slurry was filtered with a jacketed filter apparatus at $66^{\circ} \mathrm{C}$. The filtrate was diluted with water to prevent precipitation and sampled. The filtered solids were washed five times with a saturated $\mathrm{Na}_{2} \mathrm{CO}_{3}$ solution. The washed crystals and each of the spent wash liquids were sampled for analysis and the washed crystals were loaded out of the 222-S 11A hot cells to a 222-S Laboratory ventilation hood. The XRD analysis on the washed crystals revealed them to be $\sim 80 \% \mathrm{Na}_{2} \mathrm{CO}_{3} \cdot \mathrm{H}_{2} \mathrm{O}$ with $\sim 10 \% \mathrm{Na}_{2} \mathrm{CO}_{3} \cdot 10 \mathrm{H}_{2} \mathrm{O}$ and $\sim 10 \% \mathrm{Na}_{6} \mathrm{CO}_{3}\left(\mathrm{SO}_{4}\right)_{2}$; no other phases were detected.

The washed crystals were then redissolved in water and stirred and heated to near boiling in an open beaker until a freely flowing wet slurry was formed. The slurry was then filtered and the filtrate was sampled. The filtered solids were washed three times with saturated $\mathrm{NaNO}_{3}$ solution. The washed crystals and each of the spent wash liquids were sampled for analysis. The XRD analysis on the washed crystals revealed them to be $\sim 58 \% \mathrm{Na}_{2} \mathrm{CO}_{3} \cdot \mathrm{H}_{2} \mathrm{O}$ with $\sim 40 \%$ $\mathrm{Na}_{2} \mathrm{CO}_{3} \cdot 10 \mathrm{H}_{2} \mathrm{O}$ and $\sim 2 \% \mathrm{Na}_{2} \mathrm{NO}_{3}$; no other phases were detected.

\subsection{BURKEITE RUN}

The $\mathrm{Na}_{6} \mathrm{CO}_{3}\left(\mathrm{SO}_{4}\right)_{2}$ (burkeite) run began with a charge of $299.65 \mathrm{~g}(227 \mathrm{~mL})$ of SST Early feed solution to the boiling pot and heated to $66^{\circ} \mathrm{C}$. While stirring, $6.60 \mathrm{~g}$ of anhydrous $\mathrm{Na}_{2} \mathrm{CO}_{3}$ and $17.22 \mathrm{~g}$ of anhydrous $\mathrm{Na}_{2} \mathrm{SO}_{4}$ were slowly added and continuously stirred for $\sim 1 \mathrm{hr}$. The stirred boiling pot continued to be cloudy. The ESP program predicted that $\sim 16$ g of burkeite $\left[\mathrm{Na}_{6} \mathrm{CO}_{3}\left(\mathrm{SO}_{4}\right)_{2}\right]$ would precipitate out of solution at $66^{\circ} \mathrm{C}$. The contents of the boiling pot were filtered with a jacketed filter apparatus at $66^{\circ} \mathrm{C}$. The filtered solids were retained in the filter apparatus at $66^{\circ} \mathrm{C}$ and the filtrate was returned to the boiling pot. The XRD sample of the filtered solids was inadvertently missed. The boiling pot was attached to the boildown apparatus 
in the reflux position and the pressure and heat were adjusted to maintain constant boiling at $66^{\circ} \mathrm{C}$. After steady boiling was achieved, the valve was switched to collect condensate position and monitored until $\sim 80 \mathrm{~mL}$ were collected. The vacuum was released and the slurry was added to the previously filtered solids and filtered at $66^{\circ} \mathrm{C}$. The filtrate was diluted with water to prevent precipitation and sampled. The filtered solids were washed five times with a saturated $\mathrm{Na}_{2} \mathrm{CO}_{3} / \mathrm{Na}_{2} \mathrm{SO}_{4}$ solution. The washed crystals and each of the spent wash liquid were sampled for analysis and the washed crystals were loaded out of the 222-S 11A hot cells to a 222-S Laboratory ventilation hood. The XRD analysis on the washed crystals revealed them to be $\mathrm{Na}_{6} \mathrm{CO}_{3}\left(\mathrm{SO}_{4}\right)_{2}$ (burkeite) with no other phases detected.

The washed crystals were then redissolved in water and stirred and heated to near boiling in an open beaker until a freely flowing wet slurry was formed. The slurry was then filtered and the filtrate was sampled. The filtered solids were washed three times with saturated $\mathrm{Na}_{2} \mathrm{CO}_{3} / \mathrm{Na}_{2} \mathrm{SO}_{4}$ solution. The washed crystal and each of the spent wash liquid were sampled for analysis. The $\mathrm{XRD}$ analysis on the washed crystals revealed them to be $\mathrm{Na}_{6} \mathrm{CO}_{3}\left(\mathrm{SO}_{4}\right)_{2}$ with no other phases detected.

\subsection{SODIUM OXALATE RUN}

The sodium oxalate run began with a charge of $200.82 \mathrm{~g}(189 \mathrm{~mL})$ of SST Late feed solution and $200 \mathrm{~mL}$ of water to the boiling pot and heated to $66^{\circ} \mathrm{C}$. While stirring, $12.02 \mathrm{~g}$ of anhydrous $\mathrm{Na}_{2} \mathrm{C}_{2} \mathrm{O}_{4}$ were slowly added and continuously stirred for $\sim 1 \mathrm{hr}$. The stirred boiling pot continued to be cloudy and was filtered with a jacketed filter apparatus at $66^{\circ} \mathrm{C}$. The filtered solids were sampled for XRD analysis and the filtrate was returned to the boiling pot. The XRD analysis on the crystals revealed them to be primarily $\mathrm{Na}_{2} \mathrm{C}_{2} \mathrm{O}_{4}$ with $\sim 2 \% \mathrm{NaNO}_{3}$ detected (the nitrate phase was most likely the result of the filtered crystals not being washed). The boiling pot was attached to the boildown apparatus in the reflux position and the pressure and heat were adjusted to maintain constant boiling at $66^{\circ} \mathrm{C}$. After steady boiling was achieved, the valve was switched to collect condensate position and monitored until $\sim 320 \mathrm{~mL}$ were collected. The vacuum was released and the slurry was filtered with a jacketed filter apparatus at $66^{\circ} \mathrm{C}$. The filtrate was diluted with water to prevent precipitation and sampled. The filtered solids were washed five times with a saturated $\mathrm{Na}_{2} \mathrm{C}_{2} \mathrm{O}_{4}$ solution. The washed crystals and each of the spent wash liquids were sampled for analysis, and the washed crystals were loaded out of the 222-S 11A hot cells to a 222-S Laboratory ventilation hood. The XRD analysis on the washed crystals revealed them to be $\mathrm{Na}_{2} \mathrm{C}_{2} \mathrm{O}_{4}$ with no other phases detected.

The washed crystals were then redissolved in water and stirred and heated to near boiling in an open beaker until a freely flowing wet slurry was formed. The slurry was then filtered and the filtrate was sampled. The filtered solids were washed three times with saturated $\mathrm{Na}_{2} \mathrm{C}_{2} \mathrm{O}_{4}$ solution. The washed crystal and each of the spent wash liquid were sampled for analysis. The $\mathrm{XRD}$ analysis on the washed crystals revealed them to be $\mathrm{Na}_{2} \mathrm{C}_{2} \mathrm{O}_{4}$ with no other phases detected. 


\section{TOTAL ACTIVITY AND RADIONUCLIDE ANALYSES}

The filtrates and the dissolved washed crystals were analyzed as shown in Table 3-1 for tests 1-5. The spent wash solutions were analyzed for test 5 , and the solids were analyzed for test 6 .

Table 3-1. Analytical Methods for Washed Solids and Filtrate Samples.

\begin{tabular}{|c|l|l|l|}
\hline Test & \multicolumn{1}{|c|}{ Procedure } & \multicolumn{1}{|c|}{ Method } & \multicolumn{1}{c|}{ Analytes } \\
\hline 1 & La-548-121 & Gamma energy analysis & $\gamma$-emitting radionuclides, including ${ }^{137} \mathrm{Cs}$ \\
\hline 2 & LA-506-102 & $\begin{array}{l}\text { Inductively coupled plasma/mass } \\
\text { spectroscopy }\end{array}$ & ${ }^{99} \mathrm{Tc}$ \\
\hline 3 & LA-378-103 & Extraction/gamma counting & ${ }^{129} \mathrm{I}$ \\
\hline 4 & LA-220-101 & Separation/beta counting & ${ }^{90} \mathrm{Sr}$ \\
\hline 5 & LA-548-111 & Liquid scintillation & Total activity \\
\hline 6 & LT-507-101 & XRD & Solid phase identification \\
\hline
\end{tabular}

The sample analysis results are shown in Tables 3-2 and 3-3. The sample numbers can be referenced in the experimental diagrams shown in Figures 2-2 through 2-5.

The wash filtrates were analyzed for total activity, and the results are shown in Table 3-2 and plotted in Figures 3-1 and 3-2. Figure 3-1 appears to show that total activity drops rapidly for the first three washes and then levels off and approaches zero. Figure 3-2 displays the same general shape for the first three washes. It would appear that four to five washes are optimal. 
RPP-RPT-31998, Rev. 0

Table 3-2. Results of Radionuclide Analyses for Filtrates and Solids. (All units are $\mu \mathrm{Ci} / \mathrm{mL}$ except for $\mathrm{Tc}$ which is in $\mu \mathrm{g} / \mathrm{mL}$ )

\begin{tabular}{|c|c|c|c|c|c|c|}
\hline \multirow[b]{2}{*}{ Run } & \multicolumn{4}{|c|}{ Crystallication in Evaporator } & \multicolumn{2}{|c|}{ Recrystallized Sollds } \\
\hline & $\begin{array}{l}\text { Analyte } \\
\text { An }\end{array}$ & Feed $^{2}$ & $\begin{array}{l}\text { Dluted } \\
\text { Flltrate }\end{array}$ & $\begin{array}{l}\text { Dissolved } \\
\text { Washed } \\
\text { Sollds }\end{array}$ & Filtrate & $\begin{array}{l}\text { Dissolved } \\
\text { Washed } \\
\text { Solids }\end{array}$ \\
\hline \multirow[t]{6}{*}{$\mathrm{NaNO}_{3}$} & S06R00 & SST Early & 1,069 & 1,063 & 1,070 & 1,071 \\
\hline & ${ }^{137} \mathrm{Cs}$ & 59.9 & 40.3 & 0.0485 & 0.262 & $2.79 \mathrm{E}-04$ \\
\hline & ${ }^{129} \mathrm{I}$ & $5.5 E-05$ & $3.97 \mathrm{E}-05$ & $<1.99 \mathrm{E}-05$ & $<8.63 \mathrm{E}-06$ & $<2.08 \mathrm{E}-05$ \\
\hline & ${ }^{99} \mathrm{Tc}$ & 3.67 & 2.61 & $3.02 \mathrm{E}-03$ & 0.0180 & $<6.00 \mathrm{E}-04$ \\
\hline & ${ }^{89 / 90} \mathrm{Sr}$ & 0.060 & $1.15 \mathrm{E}-03$ & $4.10 \mathrm{E}-04$ & $1.27 \mathrm{E}-03$ & $6.23 \mathrm{E}-04$ \\
\hline & Total activity & ND & 49.7 & 0.0579 & 0.309 & $<9.93 \mathrm{E}-04$ \\
\hline \multirow[t]{6}{*}{$\mathrm{Na}_{2} \mathrm{CO}_{3}$} & S06R00 & SST Early & 1,083 & 1,084 & 1,085 & 1,086 \\
\hline & ${ }^{137} \mathrm{Cs}$ & 59.9 & 44.2 & 0.0320 & 0.0841 & $2.35 \mathrm{E}-04$ \\
\hline & ${ }^{129} I$ & $5.5 \mathrm{E}-05$ & 4.74E-05 & $<2.27 \mathrm{E}-05$ & $<1.67 \mathrm{E}-05$ & $<1.92 \mathrm{E}-05$ \\
\hline & ${ }^{99} \mathrm{Tc}$ & 3.67 & 2.92 & $2.09 \mathrm{E}-03$ & $4.65 \mathrm{E}-03$ & $<3.00 \mathrm{E}-04$ \\
\hline & ${ }^{82,90} \mathrm{Sr}$ & 0.060 & $5.81 \mathrm{E}-04$ & $6.93 \mathrm{E}-03$ & 0.0117 & $1.16 \mathrm{E}-03$ \\
\hline & Total activity & ND & 54.0 & 0.0522 & $2.72 \mathrm{E}-03$ & $2.72 \mathrm{E}-03$ \\
\hline \multirow[t]{6}{*}{$\mathrm{Na}_{6} \mathrm{CO}_{3}\left(\mathrm{SO}_{4}\right)_{2}$} & S06R00 & SST Early & 1,098 & 1,099 & 1,100 & 1,101 \\
\hline & ${ }^{137} \mathrm{Cs}$ & 59.9 & 58.4 & 0.0190 & 0.359 & $7.98 \mathrm{E}-05$ \\
\hline & ${ }^{129} \mathrm{I}$ & $5.5 \mathrm{E}-05$ & $5.36 \mathrm{E}-05$ & $<1.68 \mathrm{E}-05$ & $<1.84 \mathrm{E}-05$ & $<1.58 \mathrm{E}-05$ \\
\hline & ${ }^{999} \mathrm{Tc}$ & 3.67 & 3.54 & $1.26 \mathrm{E}-03$ & 0.0223 & $<3.00 \mathrm{E}-04$ \\
\hline & ${ }^{89 / 90} \mathrm{Sr}$ & 0.060 & $5.33 \mathrm{E}-04$ & 0.0151 & $3.65 \mathrm{E}-03$ & 0.0296 \\
\hline & Total activity & ND & 70.8 & 0.0521 & 0.449 & 0.0679 \\
\hline \multirow[t]{6}{*}{$\mathrm{Na}_{2} \mathrm{C}_{2} \mathrm{O}_{4}$} & S06R00 & SST Late & 1,113 & 1,114 & 1,115 & 1,116 \\
\hline & ${ }^{137} \mathrm{Cs}$ & 9.4 & 12.1 & 5.18E-03 & 0.0856 & $7.58 \mathrm{E}-05$ \\
\hline & ${ }^{129} \mathrm{I}$ & $6.9 \mathrm{E}-06$ & $1.09 \mathrm{E}-05$ & $<1.91 \mathrm{E}-05$ & $<2.47 \mathrm{E}-05$ & $<1.93 \mathrm{E}-05$ \\
\hline & ${ }^{99} \mathrm{Tc}$ & 0.601 & 0.794 & $<3.00 \mathrm{E}-04$ & 4.30E-03 & $<3.00 \mathrm{E}-04$ \\
\hline & ${ }^{8990} \mathrm{Sr}$ & 0.008 & $1.72 \mathrm{E}-03$ & $9.09 \mathrm{E}-04$ & $1.33 \mathrm{E}-05$ & $2.29 \mathrm{E}-03$ \\
\hline & Total activity & ND & 13.7 & 0.0129 & 0.0999 & $5.39 \mathrm{E}-03$ \\
\hline
\end{tabular}

Taken from Table 2-1. 
Table 3-3. Results of Total Activity Analyses for Wash Solutions.

(All units are $\mu \mathrm{Ci} / \mathrm{mL}$ )

\begin{tabular}{|c|c|c|c|c|c|c|c|c|}
\hline \multicolumn{9}{|c|}{ RPP-RPT-31998, Rev. 0} \\
\hline \multirow[b]{3}{*}{ Run } & \multicolumn{5}{|c|}{ Crystallization in Evaporator } & \multirow{2}{*}{\multicolumn{3}{|c|}{$\begin{array}{c}\text { Recrystallized Solids } \\
\text { Wash Number }\end{array}$}} \\
\hline & \multicolumn{5}{|c|}{ Wash Number } & & & \\
\hline & 1 & 2 & 3 & 4 & 5 & 1 & 2 & 3 \\
\hline Sample Number & S06R00 & S06R00 & SO6R00 & S06R00 & S06R00 & S06R00 & S06R00 & S06R00 \\
\hline \multirow[t]{2}{*}{$\mathrm{NaNO}_{3}$} & 1,058 & 1,059 & 1,060 & 1,061 & 1,062 & 1,064 & 1,065 & 1,066 \\
\hline & 36.1 & 8.83 & 0.940 & 0.221 & 0.0995 & 0.0822 & 0.0133 & $2.17 \mathrm{E}-03$ \\
\hline \multirow[t]{2}{*}{$\mathrm{Na}_{2} \mathrm{CO}_{3}$} & 1,073 & 1,074 & 1,075 & 1,076 & 1,077 & 1,078 & 1,079 & 1,080 \\
\hline & 73.9 & 15.8 & 4.13 & 1.59 & 0.497 & 0.0877 & 0.0366 & $4.89 \mathrm{E}-03$ \\
\hline \multirow[t]{2}{*}{$\mathrm{Na}_{6} \mathrm{CO}_{3}\left(\mathrm{SO}_{4}\right)_{2}$} & $1,0 \overline{8} \overline{8}$ & $1,0 \overline{8} 9$ & 1,090 & 1,091 & 1,092 & 1,093 & 1,094 & 1,095 \\
\hline & 62.2 & 17.7 & 5.21 & 1.37 & 0.501 & 0.0909 & 0.0235 & $6.86 \mathrm{E}-03$ \\
\hline \multirow[t]{2}{*}{$\mathrm{Na}_{2} \mathrm{C}_{2} \mathrm{O}_{4}$} & 1,103 & 1,104 & 1,105 & 1,106 & 1,107 & 1,108 & 1,109 & 1,110 \\
\hline & 8.17 & 1.38 & 0.769 & 0.467 & 0.345 & 7.13E-03 & $1.71 \mathrm{E}-03$ & $7.71 \mathrm{E}-04$ \\
\hline
\end{tabular}

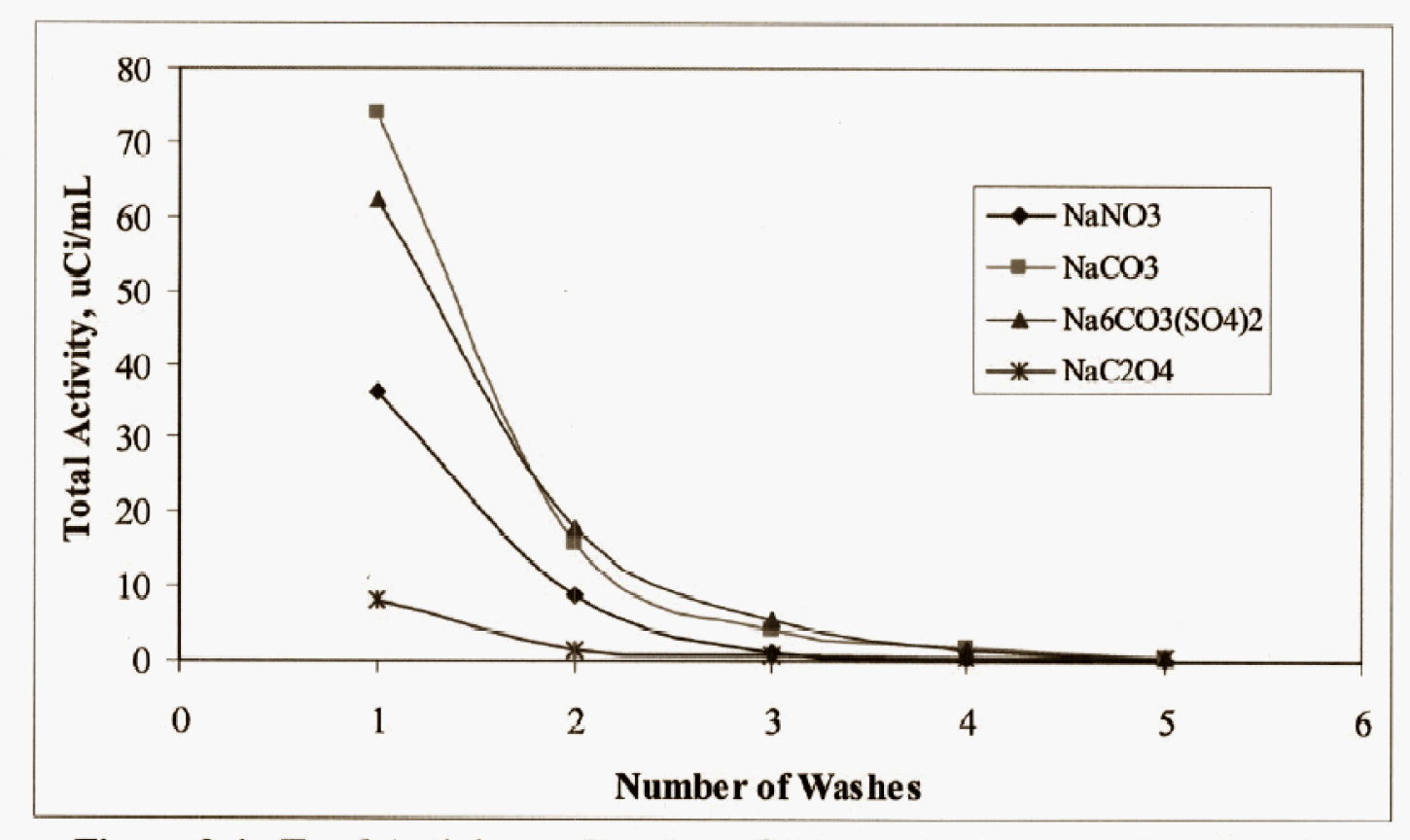

Figure 3-1. Total Activity vs. Number of Washes for Evaporation Samples.

zation in Evaporator

.


RPP-RPT-31998, Rev. 0

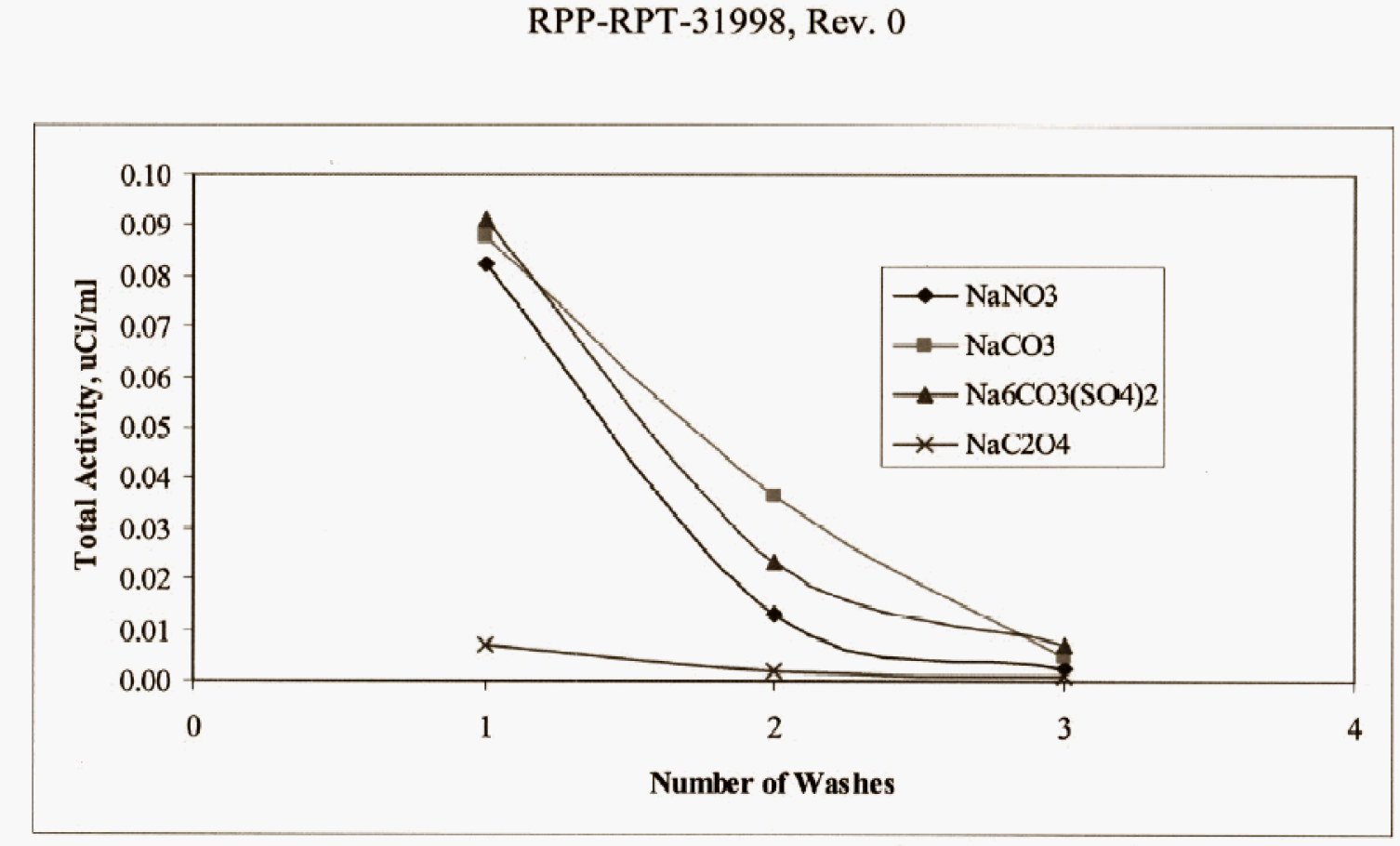

Figure 3-2. Total Activity vs. Number of Washes for Wash Samples.

(2)

\section{列}

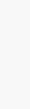




\section{RESULTS}

One way to measure the extent to which the radionuclides are being included in the crystalline solids is to calculate a decontamination factor (DF) for the radionuclides. The DF can be defined as the $\mu \mathrm{Ci} / \mathrm{mL}$ of a given radionuclide in the original liquid tank waste (the fractional crystallization feed stream) divided by the $\mu \mathrm{Ci} / \mathrm{mL}$ of that radionuclide in the supplemental treatment stream (the product of fractional crystallization) when both streams are adjusted to a common sodium concentration. Thus, for ${ }^{137} \mathrm{Cs}$ :

$$
\mathrm{DF}_{\mathrm{Cs}}=\left[{ }^{137} \mathrm{Cs}, \mu \mathrm{Ci} / \mathrm{mL} / \mathrm{Na}, \text { molar }\right]_{\text {feed }} /\left[{ }^{137} \mathrm{Cs}, \mu \mathrm{Ci} / \mathrm{mL} / \mathrm{Na}, \text { molar }\right]_{\text {product }}
$$

For these experimental runs the $\mathrm{DF}$ can be defined as the $\mu \mathrm{Ci} / \mathrm{mL}$ of a given radionuclide in the feed solution (SST Early or SST Late) divided by the $\mu \mathrm{Ci} / \mathrm{mL}$ of that radionuclide in the product of fractional crystallization (the washed solids) when both streams are adjusted to a common sodium concentration. The larger the value of DF for a radionuclide, the less that radionuclide is ending up in the crystallized product either by inclusion or by co-precipitation. The DFs for ${ }^{137} \mathrm{Cs}$ and ${ }^{90} \mathrm{Sr}$ are summarized in Table 4-1.

Table 4-1. Estimated Decontamination Factors and Percent of Initial Radionuclides Trapped in the Solids.

\begin{tabular}{|l|c|c|c|c|c|}
\hline \multicolumn{1}{|c|}{$\mathrm{Run}$} & Feed & $\mathrm{DF}_{\text {c }}$ & $\% \mathrm{Cs}$ in Sollds & $\mathrm{DF}_{\mathrm{si}}$ & $\%$ Sr in Solids \\
\hline $\mathrm{NaNO}_{3}$ & SST Early & 190 & 0.4 & 23. & 3 \\
\hline $\mathrm{Na}_{2} \mathrm{CO}_{3}$ & SST Early & 510 & 0.2 & 2.4 & 37 \\
\hline $\mathrm{Na}_{6} \mathrm{CO}_{3}\left(\mathrm{SO}_{4}\right)_{2}$ & SST Early & 760 & 0.07 & 0.96 & 56 \\
\hline $\mathrm{Na}_{2} \mathrm{C}_{2} \mathrm{O}_{4}$ & SST Late & 440 & 0.2 & 2.2 & 42 \\
\hline
\end{tabular}

Notes:

Assumptions:

(1) Addition of spiking salts does not change the volume of the feed solution.

(2) Filtered solids are $80 \%$ by wt for filtered solids for $\mathrm{NaNO}_{3}$ and $\mathrm{Na}_{2} \mathrm{CO}_{3}$ and $70 \%$ by wt for filtered solids for $\mathrm{Na}_{6} \mathrm{CO}_{3}\left(\mathrm{SO}_{4}\right)_{2}$ and $\mathrm{C}_{2} \mathrm{O}_{4}$ for purposes of calculating the moles of $\mathrm{Na}$ in the solids.

(3) Addition of solids to liquid samples adds to the volume by wt solids/2.

(4) Losses in total filtered unwashed solids are cue to wet solids remaining in the evaporation apparatus glassware.

For the SST Early composite, the $\mathrm{DF}_{\mathrm{cs}}$ is related to the weight percent of solids in the slurry. The greater the weight percent of solids in the slurry, the smaller the $D F_{C_{s}}$ or the amount of phase separation. This is because of the amount ${ }^{137} \mathrm{Cs}$ carried in the interstitial liquid with the filtered solids. An example of the DF calculation for ${ }^{137} \mathrm{Cs}$ in the $\mathrm{NaNO}_{3}$ run is shown in the following. The input data and sample numbers can be found in Table 3-2 and Figure 2-2, and the assumptions made for the purposes of these calculations are summarized in the notes for Table 4-1. 


\section{RPP-RPT-31998, Rev. 0}

\section{$\mathrm{NaNO}_{3}$ run SST Early Feed:}

The Na concentration is calculated from the analysis of the SST Early sample plus the number of moles of $\mathrm{Na}$ added as $\mathrm{NaNO}_{3}$. The final volume of the feed solution is approximated by multiplying the weight of the spiking salt by $0.5 \mathrm{~mL} / \mathrm{g}$ (e.g., for $32.26 \mathrm{~g}$ of $\mathrm{NaNO}_{3}$, the volume is adjusted by adding $26.13 \mathrm{~mL}$ ).

$$
\mathrm{Na}(\text { moles } / L)=\frac{[(6.309 \mathrm{moles} / \mathrm{L}) \times(98.3 \mathrm{~mL}) \times(1 \mathrm{~L} / 1000 \mathrm{~mL})+(32.26 \mathrm{~g} \mathrm{NaNO}) /(85.01 \mathrm{~g} / \mathrm{mole})]}{[(98.3 \mathrm{~mL}+(32.26 \mathrm{~g} \mathrm{NaNO}, \times 0.5 \mathrm{~mL} / \mathrm{g})) \times(1 \mathrm{~L} / 1000 \mathrm{~mL})]}=8.74 \mathrm{moles} / \mathrm{L}
$$

The $\mu \mathrm{Ci} / \mathrm{mL}$ of ${ }^{137} \mathrm{Cs}$ in the feed is calculated from the analysis the SST Early sample multiplied by the SST Early feed added divided by the adjusted volume of the feed.

$$
C s(\mu C i / m L)=(59.9 \mu \mathrm{Ci} / \mathrm{mL}) \times \frac{(98.3 \mathrm{~mL} \mathrm{SST} \mathrm{Early} \mathrm{vol.})}{98.3 \mathrm{~mL}+\left(32.26 \mathrm{~g} \mathrm{NaNO} \mathrm{O}_{3} \times 0.5 \mathrm{~mL} / \mathrm{g}\right)}=51.5 \mu \mathrm{Ci} / \mathrm{mL}
$$

\section{$\mathrm{NaNO}_{3}$ run SST Early Product:}

The washed $\mathrm{NaNO}_{3}$ crystals were sampled (S06R001063) by adding $2.75 \mathrm{~g}$ of the wet crystals to $14.79 \mathrm{~mL}$ of $\mathrm{H}_{2} \mathrm{O}$ and dissolving. The number of moles of $\mathrm{Na}$ in the sample were estimated by approximating the dry weight of the washed crystals by assuming the dry weight is $80 \%$ of the wet weight. The sample volume is adjusted, as shown above, by multiplying the weight of the crystals by $0.5 \mathrm{~mL} / \mathrm{g}$.

$$
\mathrm{Na}(\text { moles } / \mathrm{L})=\frac{\left[\left(2.75 \mathrm{~g} \text { wet washed } \mathrm{NaNO}_{3}\right) \times\left(0.8 \mathrm{~g} \mathrm{dry} / 1 \mathrm{~g} \text { wet } \mathrm{NaNO}_{3}\right)\right] /\left(85.01 \mathrm{~g} / \mathrm{mole}, \mathrm{NaNO}_{3}\right)}{\left[\left(14.75 \mathrm{~mL} \mathrm{H} \mathrm{H}_{2} \mathrm{O}+\left(2.75 \mathrm{gdry} \mathrm{NaNO}_{3} \times 0.5 \mathrm{~mL} / \mathrm{g}\right)\right) \times(1 \mathrm{~L} / 1000 \mathrm{~mL})\right]}=1.60 \mathrm{moles} / \mathrm{L}
$$

The $\mu \mathrm{Ci} / \mathrm{mL}$ of ${ }^{137} \mathrm{Cs}$ in the product is just the results of the analysis of sample S06R001063.

$$
\operatorname{Cs}(\mu C i / m L)=0.0485 \mu C i / m L
$$

The $\mathrm{DF}_{\mathrm{Cs}}$ is then calculated as

$$
S F_{\alpha}=\frac{[(51.46 \mu C i / m L, C s) /(8.74 \text { moles } / L, N a)]_{\text {FanD }}}{[(0.0485 \mu C i / m L, C s) /(1.63 \text { moles } / L)]_{\text {Provoct }}}=194 \text { or } \cong 190
$$

Another way to measure the extent that a radionuclide is being co-precipitated or included with one of the solid phases is to calculate the percentage of radionuclide that ends up in the crystallized product. The approximated percentages of the radionuclides ${ }^{137} \mathrm{Cs}$ and ${ }^{90} \mathrm{Sr}$ are also shown in Table 4-1 for each of the experimental runs. An example of the calculation of ${ }^{90} \mathrm{Sr}$ percentage in the $\mathrm{Na}_{2} \mathrm{C}_{2} \mathrm{O}_{4}$ run is show in the following. The input data and sample numbers can be found in Table 3-2 and Figure 2-5. 
RPP-RPT-31998, Rev. 0

\section{$\mathrm{Na}_{2} \mathrm{C}_{2} \mathrm{O}_{4}$ run SST Late Feed:}

The $\mu \mathrm{Ci}$ of ${ }^{90} \mathrm{Sr}$ in the feed is calculated from the analysis of the SST Late feed and the volume of the SST Late feed added.

$$
\operatorname{Sr}(\mu \mathrm{Ci} \text { in feed })=(0.008 \mu \mathrm{Ci} / \mathrm{mL} \text { in feed }) \times[(200.82 \mathrm{~g} \text { feed }) / 1.06 \mathrm{~g} / \mathrm{mL} \text { feed density }]=1.52 \mu \mathrm{Ci}
$$

\section{$\mathrm{Na}_{2} \mathrm{C}_{2} \mathrm{O}_{4}$ run SST Late Product:}

The washed $\mathrm{Na}_{2} \mathrm{C}_{2} \mathrm{O}_{4}$ crystals were sampled (S06R001114) by adding $0.52 \mathrm{~g}$ of the wet crystals to $10.09 \mathrm{~mL}$ of $\mathrm{H}_{2} \mathrm{O}$ and dissolving. The volume of sample was approximated by adjusting the volume of the water plus the weight of the dry crystals added multiplied by $0.5 \mathrm{~mL} / \mathrm{g}$ solids.

$$
\text { Adj. smpl.vol. }=10.09 \mathrm{~mL} \mathrm{H} \mathrm{H}_{2} \mathrm{O}+\left[\left(0.52 \mathrm{~g} \mathrm{Na} \mathrm{C}_{2} \mathrm{O}_{\imath}\right) \times(0.5 \mathrm{~mL} / \mathrm{g} \text { solids })\right]=10.35 \mathrm{~mL}
$$

The $\mu \mathrm{Ci}$ of ${ }^{90} \mathrm{Sr}$ in the product $\mathrm{Na}_{2} \mathrm{C}_{2} \mathrm{O}_{4}$ crystals is then calculated from the analysis of the S06R001114 sample and multiplied by the ratio of the total weight of filtered wet $\mathrm{Na}_{2} \mathrm{C}_{2} \mathrm{O}_{4}$ crystals to that of the wet $\mathrm{Na}_{2} \mathrm{C}_{2} \mathrm{O}_{4}$ crystals added to the sample. The total weight of the wet $\mathrm{Na}_{2} \mathrm{C}_{2} \mathrm{O}_{4}$ crystals was approximated by adding the weight of the recovered filtered crystal plus accumulated losses due to unrecovered material from the glassware. It is assumed that the bulk of the unrecovered material is in the form of wet $\mathrm{Na}_{2} \mathrm{C}_{2} \mathrm{O}_{4}$ crystals for the purposes of these calculations.

$$
\begin{gathered}
S r(\mu \mathrm{C} i \text { in product })=(0.000909 \mu \mathrm{Ci} / \mathrm{mL}) \times(10.35 \mathrm{~mL}) \times\left[\frac{\left(27.40 \mathrm{~g} \text { wet } \mathrm{Na}_{2} \mathrm{C}_{2} \mathrm{O}_{4} \text { solids weighed }+7.58 \mathrm{~g} \text { solids lost }\right)}{(0.52 \mathrm{~g} \text { wet solids sampled })}\right] \\
S r(\mu \mathrm{Ci} \text { in product })=0.633 \mu \mathrm{Ci}
\end{gathered}
$$

So the $\%{ }^{90} \mathrm{Sr}$ in the product $\mathrm{Na}_{2} \mathrm{C}_{2} \mathrm{O}_{4}$ crystals is

$$
\% \operatorname{Sr}(\text { in product })=100 \times\left[\frac{0.633 \mu \mathrm{Cl}}{1.52 \mu \mathrm{Cl} i}\right]=42 \%
$$

Still another way to measure the extent that a radionuclide is being co-precipitated or included with one of the solid phases is to compare the ratios of the radionuclide concentrations to one another. It is obvious that ${ }^{137} \mathrm{Cs}$, with a DF $\geq 90$ for all four solid phases and $<1 \%$ trapped in the solids, is not being significantly incorporated into the solids. So if the ratios of the other radionuclides that are present at significant levels $\left({ }^{129} \mathrm{I},{ }^{99} \mathrm{Tc}\right.$, and $\left.{ }^{90} \mathrm{Sr}\right)$ in the SST Early and Late feeds are calculated, any incorporation of a radionuclide in either the filtrates or filtered solids will show up as decreasing in the filtrate and increasing in the washed solids. Table 4-2 shows the calculated ratios of the radionuclides to ${ }^{137} \mathrm{Cs}$ using the analysis results from Table 3-2. 
RPP-RPT-31998, Rev. 0

Table 4-2. Ratios of Radionuclides to Cesium-137.

\begin{tabular}{|c|c|c|c|c|c|c|}
\hline \multirow[b]{2}{*}{ Run } & \multicolumn{4}{|c|}{ Crystallization in Evaporator } & \multicolumn{2}{|c|}{ Recrystallized Sollds } \\
\hline & Radionuelide & Feed & Filtrate & $\begin{array}{c}\text { Washed } \\
\text { Sollds }\end{array}$ & Flitrate & $\begin{array}{l}\text { Washed } \\
\text { Solfds }\end{array}$ \\
\hline \multirow[t]{5}{*}{$\mathrm{NanO}_{3}$} & S06R00 & SST Early & 1,069 & 1,063 & 1,070 & 1,071 \\
\hline & ${ }^{137} \mathrm{Cs}$ & 1.00 & 1.00 & 1.00 & 1.00 & 1.00 \\
\hline & ${ }^{129} \mathrm{~T}$ & $9.18 \mathrm{E}-07$ & $9.85 \mathrm{E}-07$ & --- & --- & -- \\
\hline & ${ }^{99} \mathrm{Tc}$ & $6.13 \mathrm{E}-02$ & $6.48 \mathrm{E}-02$ & $6.23 \mathrm{E}-02$ & $6.87 \mathrm{E}-02$ & $\cdots$ \\
\hline & ${ }^{89190} \mathrm{Sr}$ & $1.00 \mathrm{E}-03$ & $2.85 \mathrm{E}-05$ & 8.45E-03 & 4.85E-03 & 2.2 \\
\hline \multirow[t]{5}{*}{$\mathrm{Na}_{2} \mathrm{CO}_{3}$} & SO6R00 & SST Early & 1,083 & 1,084 & 1,085 & 1,086 \\
\hline & ${ }^{137} \mathrm{Cs}$ & 1.00 & 1.00 & 1.00 & 1.00 & 1.00 \\
\hline & ${ }^{129} \mathrm{I}$ & $9.18 \mathrm{E}-07$ & $1.07 \mathrm{E}-06$ & $\ldots$ & $\ldots$ & $\cdots$ \\
\hline & ${ }^{99} \mathrm{Tc}$ & $6.13 \mathrm{E}-02$ & $6.61 \mathrm{E}-02$ & $6.53 \mathrm{E}-02$ & $5.53 \mathrm{E}-02$ & 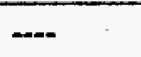 \\
\hline & ${ }^{89 / 90} \mathrm{Sr}$ & $1.00 \mathrm{E}-03$ & 1.31E-05 & $2.17 \mathrm{E}-01$ & $1.39 \mathrm{E}-01$ & 4.9 \\
\hline \multirow[t]{5}{*}{$\mathrm{Na}_{6} \mathrm{CO}_{3}\left(\mathrm{SO}_{4}\right)_{2}$} & SO6R00 & SST Early & 1,098 & 1,099 & 1,100 & 1,101 \\
\hline & ${ }^{137} \mathrm{Cs}$ & 1.00 & 1.00 & 1.00 & 1.00 & 1.00 \\
\hline & ${ }^{129} \mathrm{I}$ & $9.18 \mathrm{E}-07$ & $9.18 \mathrm{E}-07$ & $\therefore-$ & - & - \\
\hline & ${ }^{99} \mathrm{Tc}$ & $6.13 \mathrm{E}-02$ & $6.06 \mathrm{E}-02$ & $6.63 \mathrm{E}-02$ & $6.21 \mathrm{E}-02$ & - \\
\hline & ${ }^{8990} \mathrm{Sr}$ & $1.00 \mathrm{E}-03$ & $9.13 \mathrm{E}-06$ & $7.95 \mathrm{E}-01$ & $1.02 \mathrm{E}-02$ & 371. \\
\hline \multirow[t]{5}{*}{$\mathrm{Na}_{2} \mathrm{C}_{2} \mathrm{O}_{4}$} & S06R00 & SST Late & 1,113 & 1,114 & 1,115 & 1,116 \\
\hline & ${ }^{137} \mathrm{Cs}$ & 1.00 & 1.00 & 1.00 & 1.00 & 1.00 \\
\hline & 129 & $7.34 \mathrm{E}-07$ & $9.01 \mathrm{E}-07$ & --- & -- & - \\
\hline & ${ }^{99} \mathrm{Tc}$ & $6.39 \mathrm{E}-02$ & $6.56 \mathrm{E}-02$ & $\cdots$ & $5.02 \mathrm{E}-02$ & $\overline{--}$ \\
\hline & ${ }^{89 / 90} \mathrm{Sr}$ & 8.51E-04 & $1,42 \mathrm{E}-04$ & $1.75 E-01$ & $1.55 \mathrm{E}-04$ & 30. \\
\hline
\end{tabular}

The ratios for ${ }^{129} \mathrm{I}$ and ${ }^{99} \mathrm{Tc}$ remain essentially the same in the liquid and solid phases, whereas the ratios for ${ }^{90} \mathrm{Sr}$ decrease in the liquid phases and increase in the solids phases indicating that it is co-precipitating with each of the four solid phases.

An easier way to visualize the ratios is to calculate the ratios scaled to the feed solution so that all the ratios equal 1.00 for the feed solutions and for the ${ }^{137} \mathrm{Cs}$. As an example, taking the ratio in Table 4-2 for the $\mathrm{NaNO}_{3}$ run for ${ }^{129} \mathrm{I}$ in the filtrate and dividing it by the ratio in the SST Early feed solution gives $9.85 \times 10^{-07} / 9.18 \times 10^{-07}=1.07$ which indicates that ratio ${ }^{129} \mathrm{~V}^{137} \mathrm{Cs}$ is nearly the same in the SST Early feed solution as it is in the filtrate. As another example, for the $\mathrm{Na}_{6} \mathrm{CO}_{3}\left(\mathrm{SO}_{4}\right)_{2}$ run for washed solids and ${ }^{90} \mathrm{Sr}: 7.95 \times 10^{-01} / 1.00 \times 10^{-03}=793$ which indicates that the concentration of ${ }^{90} \mathrm{Sr}$ compared to ${ }^{137} \mathrm{Cs}$ in the washed crystals is 793 times greater than it was in the feed solution. Table 4-3 shows the results for all the values. 
RPP-RPT-31998, Rev. 0

Table 4-3. Ratios of Radionuclides to Cesium-137 Normalized to Feed Solution.

\begin{tabular}{|c|c|c|c|c|c|c|}
\hline \multirow[b]{2}{*}{$\mathbf{R m}$} & \multicolumn{4}{|c|}{ Crystallizat on in Evaporator } & \multicolumn{2}{|c|}{ Recrystallized Solids } \\
\hline & Radionuclide & Feed: & Fultrate & $\begin{array}{l}\text { Washed } \\
\text { Solids }\end{array}$ & Flitrate & $\begin{array}{l}\text { Washed } \\
\text { Solids }\end{array}$ \\
\hline \multirow[t]{5}{*}{$\mathrm{NaNO}_{3}$} & S06R00 & SST Early & 1,069 & 1,063 & 1,070 & 1,071 \\
\hline & ${ }^{737} \mathrm{Cs}$ & 1.00 & 1.00 & 1.00 & 1.00 & 1.00 \\
\hline & ${ }_{129}^{129}$ & 1.00 & 1.07 & - & -- & - \\
\hline & ${ }^{99} \mathrm{Tc}$ & 1.00 & 1.06 & 1.02 & 1.12 & - \\
\hline & ${ }^{89900} \mathrm{Sr}$ & 1.00 & 0.03 & 8.4 & 4.84 & 2,230 . \\
\hline \multirow[t]{5}{*}{$\mathrm{Na}_{2} \mathrm{CO}_{3}$} & S06R00 & & & & 1,085 & 1,086 \\
\hline & ${ }^{737} \mathrm{Cs}$ & 1.00 & 1.00 & 1.00 & 1.00 & 1.00 \\
\hline & ${ }^{129}{ }_{1}$ & 1.00 & 1.17 & $\rightarrow$ & - & $\overline{-}$ \\
\hline & ${ }^{9} \mathrm{Tc}$ & 1.00 & 1.08 & 1.07 & 0.90 & $\overline{--}$ \\
\hline & ${ }^{8990} \mathrm{Sr}$ & 1.00 & 0.01 & 216. & 138.89 & 4,930 \\
\hline \multirow[t]{5}{*}{$\mathrm{Na}_{6} \mathrm{CO}_{3}\left(\mathrm{SO}_{4}\right)_{2}$} & S06R00 & & & & 1,100 & 1,101 \\
\hline & ${ }^{137} \mathrm{Cs}$ & 1.00 & 1.00 & 1.00 & 1.00 & 1.00 \\
\hline & ${ }^{129} I$ & 1.00 & 1.00 & -- & $m$ & - \\
\hline & ${ }^{99} \mathrm{Tc}$ & 1.00 & 0.99 & 1.08 & 1.01 & -- \\
\hline & ${ }^{85 / 90} \mathrm{Sr}$ & 1.00 & 0.01 & 793. & 10.15 & 370310 . \\
\hline \multirow{5}{*}{$\mathrm{Na}_{2} \mathrm{C}_{2} \mathrm{O}_{4}$} & S06R00 & & & & 1,115 & 1,116 \\
\hline & ${ }^{137} \mathrm{Cs}$ & 1.00 & 1.00 & 1.00 & 1.00 & 1.00 \\
\hline & ${ }^{129} \mathbf{I}$ & 1.00 & 1.23 & - & -- & -- \\
\hline & ${ }^{99} \mathrm{Tc}$ & 1.00 & 1.03 & -- & 0.79 & - \\
\hline & ${ }^{89 \% 90} \mathrm{Sr}$ & 1.00 & 0.17 & 206. & 0.18 & 35,500 . \\
\hline
\end{tabular}




\section{CONCLUSIONS}

The test results conclusively show, with actual tank waste samples, that the four common sodium phases $\mathrm{NaNO}_{3}, \mathrm{Na}_{2} \mathrm{CO}_{3}, \mathrm{Na}_{6} \mathrm{CO}_{3}\left(\mathrm{SO}_{4}\right)_{2}$, and $\mathrm{Na}_{2} \mathrm{C}_{2} \mathrm{O}_{4}$ do show a small amount of inclusion of radionuclides. This is shown by $\mathrm{DF}_{\mathrm{Cs}}$ of between 190 and 760 and with $<1 \%$ inclusion of the ${ }^{137} \mathrm{Cs}$ in the feed into the washed solids. While there definitely are inclusions, such is the nature of crystals, the separations criteria (for ${ }^{137} \mathrm{Cs}$ and sodium) of $<1.23 \times 10^{-3} \mathrm{Ci} / \mathrm{mol} \mathrm{Na}$ were exceeded in all four of the tests performed as shown in Table 5-1. The results shown in Table 4-3 indicate that the ${ }^{129} \mathrm{I}$ and ${ }^{99} \mathrm{Tc}$ radionuclides closely follow the ${ }^{137} \mathrm{Cs}$ since their ratios are nearly equal to 1 in the feed and filtrate as well in the recrystallized solids and filtrate.

Table 5-1. All Tests Exceed Cesium-137 Activity in Product Performance Criteria.

\begin{tabular}{|c|c|c|c|}
\hline Run & Feed & $\begin{array}{l}\text { Cs Activity in } \\
\text { Product } \\
\text { (Ct/mole Na) }\end{array}$ & $\begin{array}{l}137 \mathrm{Cs} \text { Actility in } \\
\text { Product Criterta } \\
\text { (Ci/mole Na) }\end{array}$ \\
\hline $\mathrm{NaNO}_{3}$ & SST Early & $3.0 \mathrm{E}-05$ & $<1.23 \mathrm{E}-3$ \\
\hline $\mathrm{Na}_{2} \mathrm{CO}_{3}$ & SST Early & $1.3 \mathrm{E}-05$ & $<1.23 \mathrm{E}-3$ \\
\hline $\mathrm{Na}_{6} \mathrm{CO}_{3}\left(\mathrm{SO}_{4}\right)_{2}$ & SST Early & $1.0 \mathrm{E}-05$ & $<1.23 \mathrm{E}-3$ \\
\hline $\mathrm{Na}_{2} \mathrm{C}_{2} \mathrm{O}_{4}$ & SST Late & $9.9 \mathrm{E}-06$ & $<1.23 \mathrm{E}-3$ \\
\hline
\end{tabular}

The tests conclusively show that ${ }^{90} \mathrm{Sr}$ does co-precipitate with all four solid phases. This is shown by the disappearance of $83-99 \%$ of the ${ }^{90} \mathrm{Sr}$ from the filtrate when compared to ${ }^{137} \mathrm{Cs}$ and an increase of 8-790 times that of ${ }^{137} \mathrm{Cs}$ in the solid phases. On recrystallization, the increase is $2,230-370,310$ times that of the ${ }^{137} \mathrm{Cs}$ radionuclide in the solid phases. Although ${ }^{90} \mathrm{Sr}$ coprecipitates with the $\mathrm{NaNO}_{3}$ solid phase, it is not as extensive as the other phases, probably because $\mathrm{Sr}^{+2} / \mathrm{Na}^{+}$ion substitution in the $\mathrm{NaNO}_{3}$ crystal lattice is the only driving force. $\mathrm{The}^{+2}$ ionic radius (1.16 angstroms) is much closer to the $\mathrm{Na}+$ ionic radius (0.99 angstroms) than for $\mathrm{Cs}+\left(1.7\right.$ angstroms) or for $\mathrm{Tc}^{+4}$ or $\mathrm{Tc}^{+7}(0.64$ and 0.56 angstroms). The ionic radii are from Acta Crystallographica, Effective Ionic Radii in Oxides and Fluoride. The other solid phases, $\mathrm{SrCO}_{3}$ $\left(0.00109 \mathrm{~g}\right.$ in $100 \mathrm{~mL} \mathrm{H}_{2} \mathrm{O}$ at $24^{\circ} \mathrm{C}$ ), $\mathrm{SrSO}_{4}\left(0.0138 \mathrm{~g}\right.$ in $100 \mathrm{~mL} \mathrm{H}_{2} \mathrm{O}$ at $\left.30^{\circ} \mathrm{C}\right)$, and $\mathrm{SrC}_{2} \mathrm{O}_{4}$ $\left(0.00575 \mathrm{~g}\right.$ in $100 \mathrm{~mL} \mathrm{H}_{2} \mathrm{O}$ at $\left.32^{\circ} \mathrm{C}\right)$, are low solubility salts compared to $\mathrm{Sr}\left(\mathrm{NO}_{3}\right)_{2}(88.6 \mathrm{~g}$ in $100 \mathrm{~mL} \mathrm{H}_{2} \mathrm{O}$ at $30^{\circ} \mathrm{C}$ ), which add an additional driving force. The solubilities are from the American Chemical Society, Solubilities of Inorganic and Metal-Organic Compounds. There are no corresponding low-solubility $\mathrm{Cs}^{+}$salts. 
RPP-RPT-31998, Rev. 0

\section{ACKNOWLEDGEMENTS}

The author would like to extend thanks to the following people for their help with this project:

- John Smith, Carl Nick, and Florentino Gutierrez for the use of their skilled hands in the performance of manipulator operations and many other tasks in the laboratory.

- Don Geniesse (COGEMA) for providing the computer modeling.

- Steve McKinney for coordinating the efforts of the analytical laboratory.

- Dr. Dan Herting for his oversight, guidance, and helpful comments throughout the project. 
RPP-RPT-31998, Rev. 0

\section{REFERENCES}

Acta Crystallographica, 1969, Effective Ionic Radii in Oxides and Fluorides, B25, p. 925, du Pont de Nemours and Company, Wilmington, Delaware.

American Chemical Society, 1965, Solubilities of Inorganic and Metal-Organic Compounds, 1965, Washington, D. C.

CH2M-0600248, 2006, Preparation of Composite Tank Waste Samples for EM-21 Project (external letter from D. L. Herting to E. A. Nelson, COGEMA, February 2), CH2M HILL Hanford Group, Inc., Richland, Washington.

RPP-PLAN-28491, 2006, Test Plan for Fractional Crystallization Laboratory Testing, Rev. 0, CH2M HILL Hanford Group, Inc., Richland, Washington.

RPP-RPT-26474, 2005, Fractional Crystallization of Waste from Tank 241-S-112, Rev. 0, CH2M HILL Hanford Group, Inc., Richland, Washington.

RPP-RPT-27239, 2006, Hanford Medium/Low Curie Waste Pretreatment Project - Phase I Laboratory Report, Rev. 0, CH2M HILL Hanford Group, Inc., Richland, Washington.

RPP-RPT-31352, 2006, Fractional Crystallization Flowsheet Tests with Actual Tank Waste, Rev. 0, CH2M HILL Hanford Group, Inc., Richland, Washington.

WHC-EP-0915, 1996, Clean Salt Process Final Report, Westinghouse Hanford Company, Richland, Washington. 